\title{
Evaluation of Novel Insecticides as Seed Treatments to Control Rice Weevil [Sitophilus oryzae (Linnaeus)] on Maize Seeds
}

\author{
A. Padmasri ${ }^{1 *}$, C. Srinivas ${ }^{2}$, K. Vijaya Lakshmi ${ }^{3}$, T. Pradeep ${ }^{1}$ and B. Anil ${ }^{4}$
}

${ }^{1}$ Seed Research and Technology Centre, PJTSAU, Rajendranagar, Hyderabad, India

${ }^{2}$ Department of Entomology, College of Agriculture, Rajendranagar, Hyderabad, India

${ }^{3}$ Department of Entomology, College of Agriculture, Palem, Nagarkurnool, India

${ }^{4}$ Department of Environmental Science \& Technology, College of Agriculture, PJTSAU, Rajendranagar, Hyderabad, Telangana, India

*Corresponding author

\section{A B S T R A C T}

Keywords

Management, Sitophilus oryzae (L.), insecticidal seed treatment, Maize

Article Info

Accepted:

12 August 2019

Available Online:

10 September 2019
A study was conducted to evaluate the effectiveness of some newer insecticidal molecules viz., Emamectin benzoate (Proclaim 5 SG) @ 2 ppm, Spinosad (Tracer 45 SC) @ 2 ppm, Indoxacarb (Avaunt 14.5 SC) @ 2 ppm, Rynaxypyr (Coragen 20 SC) @ 2ppm, Chlorfenapyr (Intrepid 10 EC) @ 2 ppm, Profenofos (Curacron 50 EC) @ 2 ppm, Novaluron (Rimon 10 EC) @ 5 ppm, Deltamethrin 2.8 EC @ 1 ppm along with untreated control against rice weevil and to assess the storability of treated seed. All the nine treatments were replicated thrice and statistically analyzed by using completely randomized design. The data on germination percentage, seedling vigour index, moisture content (per cent), seed damage (per cent) and adult emergence at every three months interval upto nine months of storage were recorded. The results revealed that Spinosad (Tracer 45 SC) @ $2 \mathrm{ppm} \mathrm{kg}^{-1}$ seed had recorded highest germination percentage (93.67), seedling vigour index (3113), less moisture per cent (11.33), lowest infestation ( 0.33 per cent) and adult emergence (1.00) at the end of nine

\section{Introduction}

Maize (Zea mays. L) is one of most versatile emerging crop having wider adoptability under varied agro climatic conditions. Maize hybrids and varieties are reported to be highly susceptible to insect pests both in the field and storage (Gimma et al., 2008). Hence, farmers are not as such beneficiaries of this increased production and productivity potential of new varieties. More than 37 species of arthropod pests are associated with maize grain in 
storage (Abraham, 1991). Sitophilus oryzae causes enormous losses upto 100 per cent in stored maize in India and other countries (Irabagon, 1959 and Singh et al., 1974). This evidently indicates the importance of $S$. oryzae in the storage of maize seed.

Infested seed fetches lower market price due to reduced weight. Seed viability of the damaged grain is drastically reduced and affects subsequent planting (Tefera, 2012).

Storage insect pests are difficult to control due to their small size, feeding behaviour and ability to attack seed before harvest. Synthetic pesticides are the major tools for stored grain protection in developed countries. They are valued for their uniform and rapid effectiveness, ease of shipment, storage and application. Efforts have been made to identify novel insecticides which are safe to environment and economical to farmers.

\section{Materials and Methods}

A laboratory experiment was conducted at Seed Research and Technology Centre, Rajendranagar, Hyderabad during 2015-17 by using the Maize hybrid DHM 117. Freshly harvested certified seed with high germination percentage (> 99\%) and low moisture content $(<12 \%)$. The study was carried out with nine treatments viz., Emamectin benzoate (Proclaim $5 \mathrm{SG}$ ) @ 2 ppm (40.0 mg/kg seed), Spinosad (Tracer 45 SC) @ 2 ppm (4.4 ml/kg seed), Rynaxypyr (Coragen 20 SC) @ 2ppm $(0.01 \mathrm{ml} / \mathrm{kg}$ seed), Chlorfenapyr (Intrepid 10 EC) @ $2 \mathrm{ppm}(0.02 \mathrm{ml} / \mathrm{kg}$ seed $)$, Novaluron (Rimon 10 EC) @2ppm (0.02ml/kg seed), Thiamethoxam 350 FS, Profenofos (Curacron 50 EC) @2ppm $(0.004 \mathrm{ml} / \mathrm{kg}$ seed $)$ and Deltamethrin 2.8 EC @ 1.0 ppm $(0.04$ ml $/ \mathrm{kg}$ seed) and untreated control with three replications Required quantity of insecticides was diluted in $5 \mathrm{ml}$ of water to treat one $\mathrm{kg}$ of seed for proper coating. After drying in shade, seeds were packed in $2 \mathrm{~kg}$ capacity gunny bags. Similarly, control was maintained without any treatment for comparison.

Observations on seed germination (\%), seedling vigour index, seed moisture (\%), seed damage (\%) and Adult emergence were recorded at every three months interval up to nine months of experimental period. Data were analyzed statistically as per Panse and Sukhatame, 1985.

\section{Germination percentage}

It was determined by adopting the rolled paper towel method.

Germination percentage

$$
=\frac{\text { No. of seeds germinated }}{\text { Total no. of seeds germinated }} \times 100
$$

\section{Seedling vigour index}

Seedling vigour index $=$ Germination $(\%) \mathrm{x}$ Seedling length $(\mathrm{cm})$.

\section{Seed Moisture content (\%)}

The seeds were coarse ground and dried in an oven at $103 \pm 1^{\circ} \mathrm{C}$ for 17 hours, cooled in desiccators over silica gel.

The samples were weighed and the seed moisture content was calculated and expressed in percentage on wet weight basis by using following formula

Moisture content (\%)

$$
=\frac{M_{2}-M_{3}}{M_{2}-M_{1}} \times 100
$$


Where,

$\mathrm{M}_{1}$ : Weight of the empty container

$\mathrm{M}_{2}$ : Weight of the container +seed sample (before drying)

$\mathrm{M}_{3}$ : Weight of container + seed sample (after drying)

\section{Seed damage (per cent)}

From each treatment, 400 seeds were selected randomly and number of weevil infected seeds were counted and expressed as percentage seed damage.

\section{Presence/absence of insect (live and dead)}

Numbers of live/dead weevils were counted in all the treatments by taking out 400 seeds.

\section{Results and Discussion}

\section{Effect of novel insecticidal seed treatments on germination of maize seeds}

Germination percentage of maize seeds gradually decreased with the progressive increase in the storage period. Initial germination percentage was 100 per cent at initial period and after nine months of storage period the germination percentage declined to 86.48. Observations after three months of treatment imposition revealed that the highest germination percentage (99.33) was recorded in spinosad 45 SC @2 ppm, which was on par with emamectin benzoate 5 SG @ 2 ppm (97.00, rhynaxypyr 20 EC @ 2 ppm, chlorfenapyr 20 EC @2 ppm (96.00) and thiomethoxam 350 FS (95.67), deltamethrin 2.8 EC @ 1.00 ppm (98.67) followed by profenophos 50 EC @ 2ppm (94.33), novuloron 10 EC @ 5 ppm (92.67) and untreated control (90.67) were on par with each other.

After six months of storage the highest germination percentage was observed in spinosad 45 SC @ 2 ppm (94.33) and emamectin benzoate 5SG @ 2 ppm (94.33), which were on par with chlorfenapyr 10 EC @ 2 ppm (93.67) and rhynaxypyr 20 SC @ 2 ppm (92.00) treated seeds while the lowest germination was recorded in untreated seeds (86.00).

After nine months of treatment, significantly highest germination percentage was found in spinosad 45 SC @2 ppm treated seeds (93.67) followed by emamectin benzoate 5 SG @ 2 ppm (90.33) treated seeds which were on par with chlorfenapyr 10 EC @ 2 ppm (90.00). The lowest germination was recorded in untreated control (66.33).

The germination per cent of maize seeds declined progressively with increase in the period of storage in all the treatment combinations, which may be attributed to the phenomenon of ageing and depletion of food reserves and decline in synthetic activity of seed.

The results indicated that among the insecticide molecules the lowest (82.67 per cent) germination was recorded in seeds treated with novaluron 10 EC @ 5 ppm which was inferior to all other treatments except untreated control (66.33 per cent). This might be due to infestation of $S$. oryzae. The rice weevil, $S$. oryzae being an internal feeder where internal infestation might have resulted in a progressive reduction of germination which was influenced by the infestation level and the storage period

Observations after three, six and nine months of treatments imposition revealed that highest germination of $99.33,94.33$ and 93.67 per cent, respectively was observed in seeds treated with spinosad45 SC @ 2 ppm.

After nine months after treatment spinosad 45 SC @ 2 ppm and chlorfenapyr 10 EC @ 2 ppm were able to maintain germination above Indian Minimum Seed Certification Standards 
(IMSCS) i.e., 90.00 per cent (Table.1 and Fig.1).

Present findings also support the work done by Ramazan and Chahal (1989), Bhuiyah et al., (1992), Guedes and Silva (1992) and Bhujbal et al., (2001) who indicated no adverse effect of insecticides on germination of seed.

\section{Effect of novel insecticidal seed treatments on seedling vigour index of maize seeds}

Results on seedling vigour index of maize seed treated with insecticides (Table. 1 and Fig.2) revealed that after three months of treatment imposition, the highest seedling vigour index was observed in spinosad $45 \mathrm{SC}$ (a) 2 ppm (3862) treated seeds which was on par with all other insecticidal treatment except novaluron 10 EC @ 5ppm (3321), while lowest seedling vigour index was recorded in untreated control (2301).

At six months after treatment imposition higher seedling vigour index was recorded in spinosad 45 SC @ 2 ppm (3243) which was on par with emamectin benzoate 5 SG @ 2ppm (3153), chlorfenapyr 10 EC @ 2 ppm (3112), rhynaxypyr 20 EC @ 2ppm (3054), deltamethrin 2.8 EC @ 1.00 ppm (3162) and thiomethoxam 350 FS (3067) except novaluron 10 EC @ 5 ppm (3013) and profenophos 50 EC @ 2 ppm (3041). Untreated control recorded lowest seedling vigour index (1896). At nine months after treatment similar trend was observed. The highest seedling vigour index was noticed in spinosad 45 SC @2 ppm (3113) which was on par emamectin benzoate 5SG @ 2 ppm (3025), chlorfenapyr 10 EC @ 2 ppm (3009), deltamethrin 2.8 EC @ 1.00 ppm (2990) and thiomethoxam 350 FS (2954). While, untreated control recorded lowest seedling vigour index (1628).

Among the insecticidal treatments spinosad 45 SC @ 2 ppm was found to be superior over control and seedling vigour index observed was 3862, 3243 and 3113 at three, six and nine months, respectively as against 2301, 1896 and 1623 in untreated seeds at three, six and nine months, respectively. There was progressive reduction in vigour with the increase in adult emergence, weight loss, damaged seed and storage period. There was progressive reduction in vigour along with germination such decrease in vigour could be attributed to the internal and external infestation by Sitophilus oryzae which had contributed to the reduction in physiological and physical quality of maize seeds affecting the growth of the seedlings.

The present findings are in accordance with Bhogeesh et al., (2014), who reported that at six and nine months after treatment imposition, the treatments deltamethrin 100 ppm and spinosad 100 ppm recorded highest mean vigour index (2099 and 2020, respectively.

\section{Effect of novel insecticidal seed treatments on moisture content of maize seeds}

Significant differences among the treatments were observed with respect to the moisture content of maize seed at three months after treatment imposition (Table 1 and Fig. 3).

However, the lowest moisture content (8.57 per cent) was observed in spinosad 45 SC @ 2 ppm and emaectin benzoate 5 SG @ 2 ppm and highest in novaluron 10 EC @ 5 ppm (8.83 per cent).

At six months after treatment imposition results revealed that the lowest moisture content (9.63 per cent) was in spinosad $45 \mathrm{SC}$ (a) $2 \mathrm{ppm}$.

However, it was on par with emamectin benzoate 5 SG @ 2 ppm (9.67 per cent), chlorfenapyr 10 EC @ 2 ppm (9.77 per cent), thiomethoxam 350 FS (9.87 per cent), 
deltamethrin $2.8 \mathrm{EC} @ 1$ ppm (9.63 per cent) except rhynaxypyr 20 EC @ 2 ppm (10.17 per cent),novaluron10 EC@5 ppm (10.10 per cent) and profenofos $50 \mathrm{EC}$ (9.97 per cent) insecticidal seed treatment.

Table.1 Effect of novel insecticidal seed treatment on germination, seedling vigour index and moisture content of maize seeds

\begin{tabular}{|c|c|c|c|c|c|c|c|c|c|c|}
\hline \multirow[t]{2}{*}{ Treatments } & \multirow{2}{*}{$\begin{array}{l}\text { Dosage } \\
\text { kg-1 }^{-1} \\
\text { seed }\end{array}$} & \multicolumn{3}{|c|}{ Germination percentage } & \multicolumn{3}{|c|}{ Seedling vigour index } & \multicolumn{3}{|c|}{$\begin{array}{l}\text { Moisture content } \\
\quad \text { (per cent) }\end{array}$} \\
\hline & & $\begin{array}{c}3 \\
\text { MAST }\end{array}$ & $\begin{array}{c}6 \\
\text { MAST }\end{array}$ & $\stackrel{9}{\text { MAST }}$ & $\begin{array}{c}3 \\
\text { MAST }\end{array}$ & $\begin{array}{c}6 \\
\text { MAST }\end{array}$ & $\stackrel{9}{\text { MAST }}$ & $\stackrel{3}{\text { MAST }}$ & $\stackrel{6}{\text { MAST }}$ & $\stackrel{9}{\text { MAST }}$ \\
\hline $\begin{array}{l}T_{1} \text {-Emamectin } \\
\text { benzoate } 5 \mathrm{SG}) @ \\
2 \quad \mathrm{ppm}(\mathbf{4 0 . 0} \\
\mathrm{mg} / \mathrm{kg} \text { seed })\end{array}$ & $40.0 \mathrm{mg}$ & $\begin{array}{c}97.00 \\
(80.12)\end{array}$ & $\begin{array}{c}94.33 \\
(76.31)\end{array}$ & $\begin{array}{c}90.33 \\
(71.89)\end{array}$ & 3854 & 3153 & 3025 & $\begin{array}{c}8.57 \\
(17.02)\end{array}$ & $\begin{array}{c}9.67 \\
(18.11)\end{array}$ & $\begin{array}{c}11.33 \\
(19.67)\end{array}$ \\
\hline $\begin{array}{ll}T_{2} \text {-Spinosad } & 45 \\
\text { SC @ } 2 \text { ppm } & \end{array}$ & $0.004 \mathrm{ml}$ & $\begin{array}{c}99.33 \\
(84.59)\end{array}$ & $\begin{array}{c}94.33 \\
(76.45)\end{array}$ & $\begin{array}{c}93.67 \\
(75.70)\end{array}$ & 3862 & 3243 & 3113 & $\begin{array}{c}8.57 \\
(17.02)\end{array}$ & $\begin{array}{c}9.63 \\
(18.08)\end{array}$ & $\begin{array}{c}11.33 \\
(19.67)\end{array}$ \\
\hline $\begin{array}{l}\text { T }_{3} \text {-Rynaxypyr } 20 \\
\text { SC @ 2ppm }\end{array}$ & $0.01 \mathrm{ml}$ & $\begin{array}{c}95.67 \\
(78.00)\end{array}$ & $\begin{array}{c}92.00 \\
(73.57)\end{array}$ & $\begin{array}{c}89.33 \\
(70.94)\end{array}$ & 3427 & 3054 & 2628 & $\begin{array}{c}8.73 \\
(17.19)\end{array}$ & $\begin{array}{c}10.17 \\
(18.59)\end{array}$ & $\begin{array}{r}11.50 \\
(19.82)\end{array}$ \\
\hline $\begin{array}{l}T_{4^{-}} \text {Chlorfenapyr } \\
10 \text { EC @2ppm }\end{array}$ & $0.02 \mathrm{ml}$ & $\begin{array}{c}96.00 \\
(79.33)\end{array}$ & $\begin{array}{c}93.67 \\
(75.61)\end{array}$ & $\begin{array}{c}90.00 \\
(71.58)\end{array}$ & 3798 & 3112 & 3009 & $\begin{array}{c}8.63 \\
(17.09)\end{array}$ & $\begin{array}{c}9.77 \\
(18.21)\end{array}$ & $\begin{array}{c}11.37 \\
(19.70)\end{array}$ \\
\hline $\begin{array}{l}T_{5}-\text { Profenofos } 50 \\
\text { EC @ 2ppm }\end{array}$ & $0.004 \mathrm{ml}$ & $\begin{array}{c}94.33 \\
(76.27)\end{array}$ & $\begin{array}{c}90.33 \\
(71.89)\end{array}$ & $\begin{array}{c}88.67 \\
(70.33)\end{array}$ & 3671 & 3041 & 2882 & $\begin{array}{c}8.70 \\
(17.15)\end{array}$ & $\begin{array}{c}9.97 \\
(18.40)\end{array}$ & $\begin{array}{r}11.40 \\
(19.73)\end{array}$ \\
\hline $\begin{array}{l}T_{6}-\text { Novaluron } 10 \\
\text { EC @ 5ppm }\end{array}$ & $0.05 \mathrm{ml}$ & $\begin{array}{c}92.67 \\
(74.40)\end{array}$ & $\begin{array}{c}90.67 \\
(72.23)\end{array}$ & $\begin{array}{c}82.67 \\
(65.40)\end{array}$ & 3321 & 3067 & 2491 & $\begin{array}{c}8.83 \\
(17.29)\end{array}$ & $\begin{array}{c}10.10 \\
(18.58)\end{array}$ & $\begin{array}{r}11.50 \\
(19.82)\end{array}$ \\
\hline $\begin{array}{l}\mathbf{T}_{7-} \\
\text { Thiamethoxam } \\
\text { 350 FS }\end{array}$ & $3.00 \mathrm{ml}$ & $\begin{array}{l}95.67 \\
(78.00)\end{array}$ & $\begin{array}{c}90.67 \\
(72.25)\end{array}$ & $\begin{array}{l}89.33 \\
(70.94)\end{array}$ & 3501 & 3013 & 2954 & $\begin{array}{c}8.67 \\
(17.12)\end{array}$ & $\begin{array}{c}9.87 \\
(18.31)\end{array}$ & $\begin{array}{c}11.40 \\
(19.73)\end{array}$ \\
\hline $\begin{array}{l}\text { T8-Deltamethrin } \\
\text { 2.8 EC @ } 1.0 \\
\text { ppm }\end{array}$ & $0.04 \mathrm{ml}$ & $\begin{array}{c}98.67 \\
(83.45)\end{array}$ & $\begin{array}{c}90.67 \\
(72.25)\end{array}$ & $\begin{array}{c}88.00 \\
(69.74)\end{array}$ & 3614 & 3162 & 2990 & $\begin{array}{c}8.80 \\
(17.26)\end{array}$ & $\begin{array}{c}9.63 \\
(18.08)\end{array}$ & $\begin{array}{c}11.43 \\
(19.76)\end{array}$ \\
\hline $\begin{array}{l}\text { T}_{9} \text {-Untreated } \\
\text { control }\end{array}$ & & $\begin{array}{c}90.67 \\
(72.23)\end{array}$ & $\begin{array}{c}86.00 \\
(68.04)\end{array}$ & $\begin{array}{c}66.33 \\
(54.54)\end{array}$ & 2301 & 1896 & 1628 & $\begin{array}{c}8.70 \\
(17.15)\end{array}$ & $\begin{array}{c}9.73 \\
(18.18)\end{array}$ & $\begin{array}{r}11.50 \\
(19.82)\end{array}$ \\
\hline SEm \pm & & 1.67 & 1.05 & 0.79 & 172.53 & 64.03 & 76.99 & 0.07 & 0.11 & 0.02 \\
\hline $\mathrm{CD}(\mathrm{P}=0.05)$ & & 4.99 & 3.12 & 2.37 & 512.61 & 190.23 & 228.75 & 0.21 & 0.33 & 0.06 \\
\hline CV (\%) & & 3.71 & 2.49 & 2.00 & 8.58 & 3.73 & 4.86 & 0.74 & 1.06 & 0.18 \\
\hline
\end{tabular}

Figures in the parentheses are angular transformed values MAST - Months after seed treatment 
Table.2 Effect of novel insecticidal seed treatments on seed damage and adult emergence (S. oryzae)

\begin{tabular}{|c|c|c|c|c|c|c|c|}
\hline \multirow[t]{3}{*}{ Treatments } & \multirow{3}{*}{$\begin{array}{c}\text { Dosage } \\
\text { kg }^{-1} \\
\text { seed }\end{array}$} & \multicolumn{6}{|c|}{ Storage duration } \\
\hline & & \multicolumn{3}{|c|}{ Seed damage (per cent) } & \multicolumn{3}{|c|}{ Adult emergence } \\
\hline & & $\begin{array}{c}3 \\
\text { MAST }\end{array}$ & $\begin{array}{c}6 \\
\text { MAST }\end{array}$ & $\begin{array}{c}9 \\
\text { MAST }\end{array}$ & $\begin{array}{c}3 \\
\text { MAST }\end{array}$ & $\begin{array}{c}6 \\
\text { MAST }\end{array}$ & $\begin{array}{c}9 \\
\text { MAST }\end{array}$ \\
\hline $\begin{array}{l}\mathrm{T}_{1} \text {-Emamectin } \\
\text { benzoate } 5 \mathrm{SG} @ \\
2 \mathrm{ppm}\end{array}$ & $40.0 \mathrm{mg}$ & $\begin{array}{l}00.00 \\
(4.06)\end{array}$ & $\begin{array}{l}00.73 \\
(4.91)\end{array}$ & $\begin{array}{c}2.07 \\
(8.27)\end{array}$ & $\begin{array}{c}0.00 \\
(0.71)\end{array}$ & $\begin{array}{l}0.67 \\
(1.1)\end{array}$ & $\begin{array}{c}1.67 \\
(1.46)\end{array}$ \\
\hline $\begin{array}{l}\mathrm{T}_{2} \text {-Spinosad } \\
\text { 45SC @ } 2 \text { ppm }\end{array}$ & $0.004 \mathrm{ml}$ & $\begin{array}{l}00.00 \\
(4.06)\end{array}$ & $\begin{array}{l}00.00 \\
(4.06)\end{array}$ & $\begin{array}{l}00.33 \\
(4.06)\end{array}$ & $\begin{array}{c}0.00 \\
(0.71)\end{array}$ & $\begin{array}{c}0.00 \\
(0.71)\end{array}$ & $\begin{array}{c}1.00 \\
(1.23)\end{array}$ \\
\hline $\begin{array}{l}T_{3} \text {-Rynaxypyr } 20 \\
\text { SC @ } 2 \text { ppm }\end{array}$ & $0.01 \mathrm{ml}$ & $\begin{array}{c}2.09 \\
(8.31)\end{array}$ & $\begin{array}{c}3.44 \\
(10.69)\end{array}$ & $\begin{array}{c}5.44 \\
(13.49)\end{array}$ & $\begin{array}{c}2.00 \\
(1.58)\end{array}$ & $\begin{array}{c}4.67 \\
(2.27)\end{array}$ & $\begin{array}{c}9.00 \\
(3.08)\end{array}$ \\
\hline $\begin{array}{l}T_{4} \text {-Chlorfenapyr } \\
10 \text { EC @ } 2 \text { ppm }\end{array}$ & $0.02 \mathrm{ml}$ & $\begin{array}{l}00.00 \\
(4.06)\end{array}$ & $\begin{array}{l}1.05 \\
(5.73)\end{array}$ & $\begin{array}{c}2.38 \\
(8.84)\end{array}$ & $\begin{array}{c}0.00 \\
(0.71)\end{array}$ & $\begin{array}{l}1.33 \\
(1.34)\end{array}$ & $\begin{array}{c}2.67 \\
(1.77)\end{array}$ \\
\hline $\begin{array}{l}T_{5} \text {-Profenofos } 50 \\
\text { EC @ } 2 \text { ppm }\end{array}$ & $0.004 \mathrm{ml}$ & $\begin{array}{c}1.93 \\
(7.98)\end{array}$ & $\begin{array}{c}2.76 \\
(9.52)\end{array}$ & $\begin{array}{c}4.16 \\
(11.77)\end{array}$ & $\begin{array}{c}1.67 \\
(1.46)\end{array}$ & $\begin{array}{c}4.67 \\
(2.27)\end{array}$ & $\begin{array}{c}7.33 \\
(2.79)\end{array}$ \\
\hline $\begin{array}{l}T_{6} \text {-Novaluron } 10 \\
\text { EC @ } 5 \text { ppm }\end{array}$ & $0.05 \mathrm{ml}$ & $\begin{array}{c}2.22 \\
(8.56)\end{array}$ & $\begin{array}{c}3.66 \\
(11.02)\end{array}$ & $\begin{array}{c}6.40 \\
(14.66)\end{array}$ & $\begin{array}{c}3.00 \\
(1.86)\end{array}$ & $\begin{array}{l}7.00 \\
(2.74)\end{array}$ & $\begin{array}{l}11.33 \\
(3.44)\end{array}$ \\
\hline $\begin{array}{l}T_{7-} \\
\text { Thiamethoxam } \\
\text { 350 FS }\end{array}$ & $3.00 \mathrm{ml}$ & $\begin{array}{l}00.00 \\
(4.06)\end{array}$ & $\begin{array}{c}1.07 \\
(5.94)\end{array}$ & $\begin{array}{c}2.48 \\
(9.06)\end{array}$ & $\begin{array}{c}0.00 \\
(0.71)\end{array}$ & $\begin{array}{c}2.00 \\
(1.56)\end{array}$ & $\begin{array}{c}3.67 \\
(2.04)\end{array}$ \\
\hline $\begin{array}{l}\text { T8-Deltamethrin } \\
\text { 2. } 8 \text { EC @ } 1.0 \\
\text { ppm }\end{array}$ & $0.04 \mathrm{ml}$ & $\begin{array}{c}1.00 \\
(5.75)\end{array}$ & $\begin{array}{c}1.84 \\
(7.79)\end{array}$ & $\begin{array}{c}3.17 \\
(10.23)\end{array}$ & $\begin{array}{c}0.33 \\
(0.88)\end{array}$ & $\begin{array}{c}2.33 \\
(1.68)\end{array}$ & $\begin{array}{c}3.67 \\
(2.04)\end{array}$ \\
\hline $\begin{array}{l}T_{9} \text {-Untreated } \\
\text { control }\end{array}$ & & $\begin{array}{c}2.39 \\
(8.88)\end{array}$ & $\begin{array}{c}6.23 \\
(14.44)\end{array}$ & $\begin{array}{l}13.66 \\
(21.69)\end{array}$ & $\begin{array}{l}10.67 \\
(3.34)\end{array}$ & $\begin{array}{l}26.33 \\
(5.18)\end{array}$ & $\begin{array}{c}52 \\
(7.24)\end{array}$ \\
\hline SEm \pm & & 0.13 & 0.42 & 0.29 & 0.10 & 0.11 & 0.08 \\
\hline CD $(P=0.05)$ & & 0.39 & 1.26 & 0.88 & 0.27 & 0.33 & 0.25 \\
\hline $\mathrm{CV}(\%)$ & & 3.7 & 8.93 & 4.52 & 12.14 & 9.48 & 5.33 \\
\hline
\end{tabular}

Figures in the parentheses are transformed values MAST: Months after seed treatment 


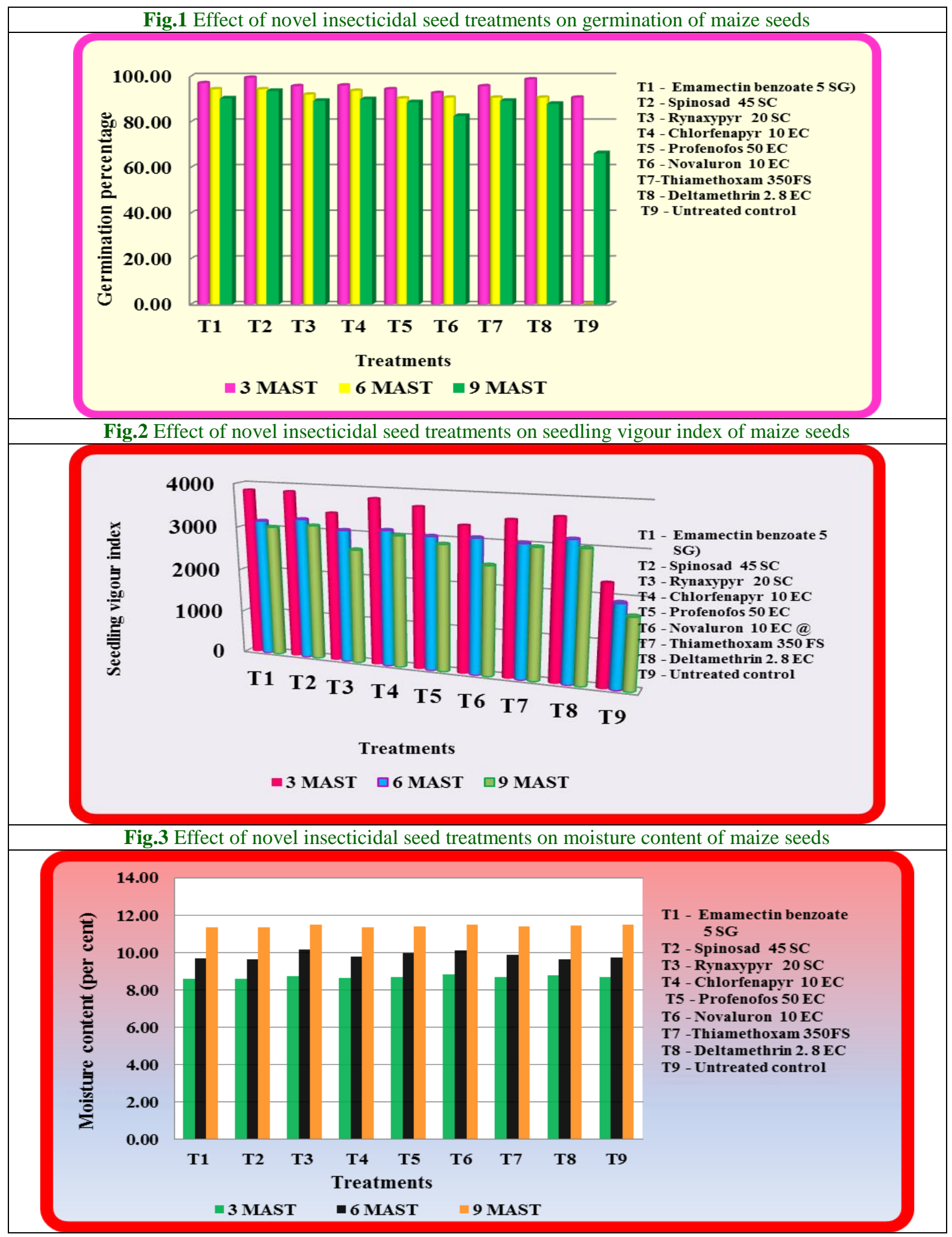

At nine months after treatment imposition, lowest moisture content of 11.33 per cent was observed in spinosad $45 \mathrm{SC}$ and emaectin benzoate 5 SG @ 2 ppm on par with chlorfenapyr 10 EC @ 2ppm (11.37 per cent). The moisture content in the rest of the 
insecticidal treatments varied from 11.40 to 11.50 per cent. The highest moisture content (11.50 per cent) was observed in untreated seeds.

The present results are in consonance with Sinha and Sinha (1992) who reported a increase in moisture content of the grain as a result of infestation by $S$. oryzae in maize. Similarly,

Malarkodi and Srimathi (2001) reported that the moisture absorption by the seed of maize was found to be in increasing order with advance in storage period.

\section{Effect of novel insecticidal seed treatments on seed damage due to $S$. oryzae}

Insecticidal seed treatments viz., spinosad 45 SC @ 2 ppm, emamectin benzoate 5 SG @ 2 ppm, chlorfenapyr 10 EC @ 2 ppm and thiomethoxam 350 FS gave complete protection to maize seed without any damage at three months after treatment.

However, maximum damage was observed in untreated check (2.39 per cent) (Table.2).

At six months after treatment imposition, per cent damage seeds were nil in spinosad 45 SC @2 ppm which was on par with emamectin benzoate 5 SG @ 2 ppm (0.73 per cent), chlorfenapyr 10 EC @ 2 ppm (1.05 per cent) and thiomethoxam 350 FS (1.05 per cent). All the treatments were found to be statistically superior over untreated control (6.25 per cent).

At nine months after treatment the significantly lowest damage was recorded in spinosad 45 SC @ 2 ppm (0.33 per cent) followed by emamectin benzoate 5 SG @ 2 ppm (2.07 per cent), chlorfenapyr 10 EC @ 2 ppm, (2.38 per cent) and thiomethoxam 350 FS (2.48 per cent), which were on par with each other. However, maximum damage was observed in untreated seed (13.66 per cent) and found significantly inferior over all other treatments.
The present results are in accordance with the findings of Fang et al., (2002) who reported that spinosad was effective against $S$. oryzae, $O$. surinamensis and T.castaneum on wheat seeds at $1 \mathrm{mg} \mathrm{kg}^{-1}$. Sharma and Michaelraj (2006) reported that complete mortality of $S$. oryzae adults was obtained with 1.0 and 2.0 $\mathrm{mg}$ a.i. spinosad per $\mathrm{kg}$, whereas, 96.7 per cent mortality was obtained with $0.5 \mathrm{mg}$ a.i. spinosad $\mathrm{kg}^{-1}$ in maize seeds. Seed damage of 0.7 and 5.3 per cent and progeny production of 0.3 and 2.0 were recorded for 1.0 and 0.5 $\mathrm{mg}$ a.i. spinosad $\mathrm{kg}^{-1}$ maize seed, respectively. Similar to the present results, Kurdikeri et al., (1994) reported that per cent seed damage and loss in weight increased with increase in storage period.

\section{Effect of novel insecticidal seed treatments on adult emergence of $S$. oryzae}

The data on effect of insecticidal seed treatments on adult emergence of Sitophilus oryzae are presented in Table 2.

There was no emergence of adult rice weevils in emamectin benzoate 5 SG @ 2 ppm, spinosad 45 SC @ 2 ppm, chlorfenapyr 10 EC @ 2 ppm and thiomethoxam $350 \mathrm{FS}$, followed by deltamethrin 2.8 EC @ 2 ppm (0.33) treated seeds after three months of treatment.

However, maximum number of adults emerged in untreated seeds (10.67), which was significantly inferior over all other treatments.

At six months after seed treatment there was no emergence of Sitophilus oryzae in spinosad 45 SC @ 2 ppm followed by emamectin benzoate 5 SG @ 2 ppm (0.67). All the insecticidal treatments were significantly superior over the control which recorded 26.33 adults.

At nine months after seed treatment similar trend was observed where least number of adults were emerged in spinosad 45 SC @ 2 ppm treated seeds (1.00) followed by 
emamectin benzoate 5 SG @ 2 ppm (1.67). However, untreated control (5.2) was significantly inferior over all other insecticidal treatments. Similar observations were also made by Abraham (1991) who has indicated that the extent of damage during storage period depends on the number of adults emerged during each generation.

The high rate of adult emergence might be due to production of second generation resulting in total increase in number of adult emergence.

Studies conducted with novel insecticides as seed treatments revealed superior performance of spinosad45 SC @ 2 ppm as it maintained seed damage below permissible limit and germination above $>90$ per cent upto nine months of storage.

\section{References}

Abraham, T. 1991. The biology, significance and control of the maize weevil S.zeamais (Coleoptera:

Curculionidae) on stored maize. M.sc. thesis. Haramaya University of Agriculture, Ethiopia.

Bhogeesh,B.M., Mutthuraju,G.P., Pradeepa, S.D., Thirumalaraju, G.T., Pannure, A and Bommesha, B. 2014. Evaluation of newer insecticides as fabric treatment against Caryedon serratus (Oliver) (Coleoptera: Bruchidae) on stored groundnut. International Journal of Plant Protection. 7 (1): 35 40.

Bhuiyah, A.N.M.R., Alam, M.I.M and Karim, S. 1992. Losses to stored rice caused by rice weevil and angoumois grain moth, and their control in Bangladesh. Bangladesh Journal of Agricultural Sciences. 19(1): 13-18.

Bhujbal, A.R., Bhole, S.R and Karmakar,
M.S. 2001. Effect of residual toxicity of some insecticides and neem oil as pigeonpea seed protection on loss in seed weight and germination of seed against Callasobruchus maculates. Pestology. 25(2):14-17.

Fang, L., Subramanyam, B. and Arthur, F. (2002a) Effectiveness of spinosad against five stored product insects on four classes of wheat. Journal of Economic Entomology, 95, 640-650

Gimma D, Tadele T. and Abraham, T 2008. Importance of husk covering on field infestation of maize by Sitophilus zeamais Motsch (Coleoptera:Curculionidea) at Bako, Western Ethiopia, African Journal of Biopesticides 7(20):3777-3782.

Guedes, F.A.P.da and Silva, R.N.C.1992. Evaluation of the residual effects of the insecticide abamectin for the control of Sitophilus zeamais Motschulsky (Coleoptera: Curculionidae) in stored maize. Revista Ceres. 39(225): 435-442.

Irabagon, I. A., 1959, Rice weevil damage to stored corn. Journal Economic Entomology, 52: 1130- 1136.

Kurdikeri, V.K., Aswathaiah, M.B., Katagall, B and Vasudevan, R.D. 1994. Extent of seed damage, loss in weight and loss of viability due to infestation of the rice weevil Sitophilus oryzae Linn. (Coleoptera: Curculionidae) in maize hybrids. Karnataka Journal of Agricultural Sciences. 7(3): 296-299.

Malarkodi, K and Srimathi, P. 2001. Effect of insecticide treatment on maintenance of seed quality in maize cv. Co-1. Seed Research. 29 (2): 197-201.

Panse, V.G and Sukhatme, P.V. 1978. Statistical methods for Agricultural workers. ICAR New Delhi.

Ramazan, N and Chahal, B.S. 1989. Effect of grain protectants on viability of wheat seeds. Seed research. 17 (1): 47-54. 
Sharma, S and Michaelraj, R.K. 2006. Efficacy of spinosad as seed protectant against the pests of stored maize. Pesticide Research Journal. 18(2):173-176.

Singh. K., Agarwal, N. S and Girish, G. K. 1974. Studies on quantitative loss in various high yielding varieties of maize due to Sitophilus oryzae (L.) (Coleoptera: Curculionidae). Journal of Science and Technology. 12 : 3-4.

Sinha, K.K and Sinha, A.K. 1992. Impact of stored grain pests on seed deterioration and aflatoxin contamination in maize. Journal of Stored Products Research. 28(3):211219.

Tefera, T. 2012. Post-harvest losses in Africa maize in face of increasing food shortage. Food Science. 4: 267-277

\section{How to cite this article:}

Padmasri, A., C. Srinivas, K. Vijaya Lakshmi, T. Pradeep and Anil, B. 2019. Evaluation of Novel Insecticides as Seed Treatments to Control Rice Weevil [Sitophilus oryzae (Linnaeus)] on Maize Seeds Int.J.Curr.Microbiol.App.Sci. 8(09): 765-774.

doi: https://doi.org/10.20546/ijcmas.2019.809.092 